\title{
Kajian Ekolinguistik Metaforis Nilai-Nilai Kearifan Lokal Upacara Pernikahan Adat Manggarai, Flores, Nusa Tenggara Timur
}

\author{
Fransiskus O. Sanjaya ${ }^{1)}$, R. Kunjana Rahardi ${ }^{2)}$ \\ kunjana.rahardi@gmail.com \\ Program Studi Magister Pendidikan Bahasa Indonesia, \\ Universitas Sanata Dharma Yogyakarta ${ }^{12)}$
}

\begin{abstract}
Abstrak. Tujuan penelitian dalam perspektif ekolinguisitk metaforis ini adalah untuk mendeskripsikan nilai-nilai kearifan lokal yang terdapat dalam upacara pernikahan adat masyarakat Manggarai, Flores, Nusa Tenggara Timur. Deskripsi makna nilai kearifan lokal tidak dapat dilepaskan dari wujud kearifan lokal itu sendiri. Penelitian ini menggunakan pendekatan kualitatif. Data dikumpulkan dengan metode simak, cakap, dan wawancara. Data yang terkumpul diklasifikasikan dan selanjutnya dianalisis dengan metode padan. Metode padan merupakan metode analisis bahasa yang alat penentunya di luar, terlepas, dan tidak menjadi bagian dari bahasa (langue) yang bersangkutan. Peneliti menggunakan analisis data, metode padan ektralingual, yaitu metode analisis yang digunakan untuk menghubungkan masalah bahasa dengan hal yang ada di luar bahasa, yakni konteks sosial dan konteks budaya masyarakat Manggarai. Hasil penelitian menunjukkan bahwa kearifan lokal dalam upacara pernikahan adat Manggarai berwujud nyata (tangible) dan tidak nyata (intangible). Kearifan lokal tangible berupa tuak, sirih pinang, belis, cincin, telur ayam kampung dan ayam jantan putih, sedangkan kearifan lokal yang intangible berupa ungkapan-ungkapan (goet). Kearifan lokal yang bersifat tangible mengandung makna persaudaraan, ketulusan hati, cinta kasih dan keturunan. Sementara itu, kearifan lokal yang bersifat intangible mengandung makna sopan santun, gadis, perjuangan, kerendahan hati dan keturunan.
\end{abstract}

Kata kunci: nilai-nilai kearifan lokal, upacara pernikahan adat, masyarakat Manggarai, linguistik metaforis

\section{Pendahuluan}

Bahasa adalah alat komunikasi antar anggota masyarakat berupa lambang bunyi yang dihasilkan alat ucap manusia (Devianty, 2017). Sementara itu, menurut Bahagia Tarigan (2016), bahasa tidak sebatas alat komunikasi. Lebih dari itu, bahasa mengandung visi budaya, merekam, memelihara, dan mewariskan konsep-konsep kolektif, nilai-nilai historis, religius filosofi, sosiobudaya, dan ekologis dari masyarakat tempatan. Berdasarkan dua pandangan di atas, disimpulkan bahwa selain sebagai alat komunikasi, bahasa dapat digunakan untuk mencatat dan mewariskan nilai-nilai budaya. Lier (2004) mengungkapkan bahwa ingatan memunculkan bahasa dan bahasa memunculkan kenangan. Dari pernyataan tersebut, kita dapat menyimpulkan bahwa apa yang ada dalam pikiran kita mengenai suatu fenomena lingkungan merupakan fenomena bahasa juga.

Dengan demikian, bahasa adalah milik manusia yang menyatu dengan kehidupannya. Tanpa bahasa, manusia tidak dapat memahami identitas dirinya. Troike (2003) mengungkapkan pada tingkat masyarakat, bahasa melayani banyak fungsi. Pemilihan bahasa sering kali berkaitan dengan tujuan politik, berfungsi untuk membuat atau memperkuat batas dalam rangka menyatukan pembicara sebagai anggota komunitas tutur tunggal dan untuk mengecualikan orang luar komunikasi intragroup. Pemberian bahasa yang demikian pun berdampak pada pengkajian 
bahasa itu sendiri. Para peneliti bahasa mengkaji bahasa menggunakan pendekatan yang berbeda-beda. Pada awalnya kajian bahasa hanya terbatas pada tataran struktural, kini meluas pada tataran fungsional. Bahkan bersinergi dengan ilmu lain, seperti ekologi dan bahasa, sosiologi dan bahasa, psikologi dan bahasa. Hal demikian dilakukan untuk memperdalam pengetahuan mengenai bahasa.

Penelitian ini dilakukan dalam kerangka ekolinguistik metaforis. Ekolinguistik adalah kolaborasi antara ilmu ekologi dan ilmu bahasa. Melalui ekolinguistik kita mempelajari fenomena-fenomena ekologi dalam kaitannya dengan bahasa. Ekologi bahasa adalah istilah yang baru. Istilah 'ekologi bahasa' muncul pertama kali pada tahun 1970an ketika Einar Haugen menciptakan paradigma ekologi bahasa. Pandangan Haugen ekologi bahasa adalah kajian tentang interaksi bahasa dengan lingkungannya. Haugen menggunakan konsep lingkungan bahasa secara metaforis, yakni dipahami sebagai masyarakat pengguna bahasa, sebagai salah satu kode bahasa, bahasa berada hanya dalam pikiran penuturnya, dan oleh karenanya bahasa berfungsi hanya apabila digunakan untuk menghubungkan antar penutur, dan menghubungkan penutur dengan lingkungannya, baik lingkungan sosial atau lingkungan alam (Subiyanto, 2013).

Linguistik ekologis berbeda dengan model struktural yang hanya dapat diselediki oleh bahasa itu sendiri, bukan lingkungannya (Vinke; Verlag, 1998). Dengan demikian, lingkungan bahasa yang sesungguhnya adalah lingkungan sosial tempat bahasa dan setiap penutur bahasa hidup dan berinteraksi, berinterelasi, berinterdependensi dengan sesama penutur dan tentunya dengan alam di lingkungan itu (Haugen, 1972). Di sisi lain, bahasa adalah bagian dari sistem pesan yang terkait dengan semua sistem indera kita, dan semua ingatan kita, dan semua cerita yang kita bangun untuk menciptakan dan memelihara identitas kita. Tidaklah mungkin untuk memutuskan bahasa dari semua ikatan itu. Hal ini adalah kunci untuk menghubungkan bahasa ke ekologi dan semiotik (Lier, 2004). Dengan kata lain, untuk memahami lingkungan kita memerlukan bahasa. Dengan demikian, bahasa dan lingkungan adalah dua hal yang tidak terpisahkan.

Dua dekade setelah diciptakannya paradigma ekologi bahasa, barulah muncul istilah 'ekolinguistik' ketika Michael Halliday (1990) pada konferensi AILA yang diselenggarakan di Thessaloniki memaparkan hubungan antara bahasa dan masalah lingkungan. Karya awal Halliday juga masuk dalam ekokritik, di mana kedua sistem bahasa dan manifestasinya dalam berbagai untaian wacana dikritik tidak ekologis dan demikian membawa sebagian dari tanggung jawab untuk degradasi lingkungan dalam semua bentuknya. Karya ekolinguistik yang dibangun di atas wawasan Halliday membentuk 'tradisi Hallidayan", yang bertujuan menciptakan kesadaran terhadap antroposintrisme linguistik (Todd Levasseur, 2015). Dari uraian di atas, disimpulkan bahwa ekolinguistik terbagi menjadi dua, yaitu ekolinguistik alami dan ekolinguistik metaforis. Ekolinguistik alamiah adalah ilmu bahasa yang bersinergi dengan lingkungan alamiah, sedangkan ekolinguistik metaforis adalah ilmu bahasa yang bersinergi dengan kehidupan sosial masyarakat (Subiyanto, 2013).

Penelitian ekolingusitik ini mengakomodasi pembatasan linguistik metaforis karena setiap diskusi tentang nilai kearifan lokal tidak dapat dipisahkan dari konteks sosial, budaya, dan etnis di mana nilainya hidup (Rahardi, 2018; Rahardi \& Setyaningsih, 2019). Kearifan lokal merupakan entitas yang sangat penting bagi martabat manusia di masyarakat Indonesia (Geertz, 
1973; Vitasurya 2016). Oleh karena itu, kearifan lokal perlu dilestarikan demi kehidupan manusia yang lebih baik. Penelitian ini mengambil pokok bahasan wujud dan makna kearifan lokal dalam upacara pernikahan adat masyarakat Manggarai dari perspektif ekolinguistik. Kearifan lokal adalah pandangan hidup dan ilmu pengetahuan serta berbagai strategi kehidupan yang berwujud aktivitas yang dilakukan oleh masyarakat lokal dalam menjawab berbagai masalah dalam pemenuhan kebutuhan mereka (Fajarini, 2014).

Selain itu, kearifan lokal juga dapat diartikan sebagai pengetahuan lokal yang sudah sedemikian menyatu dengan sistem kepercayaan, norma, dan budaya serta diekspresikan tradisi dan mitos yang dianut dalam jangka waktu yang lama (PDSPK, 2016). Senada dengan itu, menurut UU No. 32 tahun 2009 tentang Perlindungan dan Pengelolaan Lingkungan Hidup, kearifan lokal didefinisikan sebagai nilai-nilai luhur yang berlaku dalam tata kehidupan masyarakat untuk antara lain melindungi dan mengelola lingkungan hidup secara lestari. Kearifan lokal merupakan suatu filosofi dan pandangan hidup yang terwujud dalam berbagai bidang kehidupan seperti dalam tata nilai sosial dan ekonomi, arsitektur, kesehatan, tata lingkungan dan masih banyak lagi terapannya. Dengan demikian, disimpulkan bahwa kearifan lokal adalah kekhasan yang dimiliki kelompok etnis tertentu.

Menurut Koentjaraningrat (PDSPK, 2016), kearifan lokal dapat terwujud ke dalam: (a) gagasan, ide, nilai, norma, peraturan; (b) pola perilaku, kompleks aktivitas; (c) artefak, kebudayaan, material, dan benda hasil budaya. Selain itu, kearifan lokal dapat terwujud ke dalam wujud nyata (tangible) dan tidak berwujud (intangible). Bentuk kearifan lokal yang berwujud nyata antara lain (a) tekstual, seperti sistem nilai, tata cara, ketentuan khusus yang dituangkan, dalam bentuk catatan tertulis seperti dalam kitab tradisional primbon, kalender dan prasi atau tulisan di atas daun lontar; (b) bangunan/arsitektur; (c) benda cagar budaya/tradisional/karya seni. Sementara itu, kearifan lokal yang tidak berwujud misalnya petuah yang disampaikan secara verbal dan turun temurun yang dapat berupa nyanyian dan kidung yang mengandung nilai-nilai ajaran tradisional. Melalui kearifan lokal yang tidak berwujud inilah, nilai-nilai sosial disampaikan dari generasi ke generasi.

Bahasa, baik lisan maupun tulisan mengandung maksud yang ingin disampaikan penuturnya. Maksud penutur itulah yang disebut dengan makna. Berbicara mengenai makna, Cruse (2000:12) mengungkapkan bahwa semua makna berpotensi tercermin dalam maksud komunikatif. Sementara itu, Leech (2003:19) mengungkapkan makna sebagai semua yang dikomunikasikan melalui bahasa. Leech memilah makna dalam pengertian yang lebih luas ke dalam tujuh unsur yang berbeda, yaitu (1) makna konseptual, (2) makna konotatif, (3) makna stilitik dan afektif, (4) makna reflektif dan makna kolokatif, (5) makna asosiatif, (6) dan makna tematik. Selain Leech, Chaer (2014) menjelaskan ragam makna berdasarkan dikotomi makna leksikal dan makna gramatikal, denotatif dan konotatif, konseptual dan asosiatif, kata dan istilah, dan lugas dankias.

Selain kedua ahli di atas, Sofroniou (1989) dalam Structural Semantic of Byzantine Greekmenjelaskan 9 jenis makna, yaitu (1) sinonim, (2) antonim, (3) hiponim, (4) adjektif, (5) paranomasiae, (6) komplementasi, (7) konsekuensi, (8) proportionality, (9) collocations clichés and idioms, (9) parafrasa. Apabila mencermati pandangan ketiga ahli di atas mengenai makna, ketiga-tiganya mengatakan hal yang sama, penamaannya saja yang berbeda. Hal itu disebabakan 
ketiga ahli tersebut datang dari sudut pandang yang berbeda.

Menurut perspektif Haugen, manusia berada dalam lingkungan yang mengisi dan berpengaruh terhadap keberadaannya di muka bumi ini. Lingkungan tersebut merupakan lingkungan alam semesta ragawi dan lingkungan sisiobudaya. Lingkungan-lingkungan inilah yang disebut Haugen sebagai lingkungan ekologis (Nuzwaty, 2019). Upacara adat pernikahan adalah bagian dari lingkungan sisio-budaya manusia, dan pernikahan adat adalah kebudayaan yang masih dipertahankan sampai saat ini di Indonesia. Pernikahan adat di semua daerah di Indonesia memiliki tujuan yang sama, tetapi proses ritual pernikahannya berbeda-beda. Misalnya, pernikahan adat di Manggarai berbeda dengan pernikahan adat di Jambi, walaupun memiliki tujuan yang sama. Perbedaan-perbedaan yang dimaksud dapat dilihat dari perantiperanti yang digunakan dan aspek filosofisnya. Peranti-peranti atau aspek filosofis dalam pernikahan adat adalah kearifan lokal bagi masyarakat pemiliknya. Kearifan-kearifan lokal yang ada mengandung makna dan nilai-nilai yang dijadikan pedoman bagi masyarakat pemiliknya.

Pernikahan adat Manggarai terdapat nilai-nilai kearifan lokal yang dapat bermanfaat bagi masyarakat Manggarai. Nilai-nilai kearifan lokal yang ada dapat dilihat dari peranti-peranti, peribahasa (go'et), dan aspek filosofisnya. Namun, nilai-nilai kearifan lokal yang terkandung dalam pernikahan adat Manggarai tidak pernah diketahui generasi masa kini, bahkan dianggap warisan budaya yang hanya perlu diketahui orang tua. Padahal, dalam kondisi bangsa Indonesia yang sangat terpuruk etika sopan santun, perlu ditanamkan nilai-nilai budaya lokal. Aspek-aspek budaya lokal seperti dalam pernikahan adat Manggarai perlu dikaji dan digali secara mendalam makna dan nilainya, agar generasi masa kini tidak lebih mengagungkan budaya dari luar bangsa Indonesia.

Kajian terdahulu mengenai pernikahan adat Manggarai telah banyak dilakukan. Kajian ihwal pernikahan Manggarai telah dilakukan oleh Jeli dan Purawati dengan Judul "Sistem Perkawinan Adat Manggarai Dalam Perspektif Gender, Desa Nggalak Kecamatan Reok Barat Kabupaten Manggarai Tengah" (2019). Hasil penelitian menunjukkan Sistem kekerabatan yang berlaku di desa Nggalak adalah sistem kekerabatan patrilineal yang menekankan kekuasaan dalam pengambilan keputusan ada pada pihak laki-laki. Sehubungan dengan hal tersebut bahwa sistem perkawinan adat Desa Nggalak Manggarai dalam perspektif gender, dikenal istilah belis. Belis merupakan seperangkat maskawin yang diberikan oleh pihak laki-laki kepada pihak perempuan.

Penentuannya belis ini besarannya sangat bervariasi tergantung hasil mufakat dari kedua belah pihak dan dikonstruksi secara sosial dengan melihat berbagai hal yang berkaitan dengan status sosial, tingkatan pendidikan. Tujuan dari belis ini adalah untuk membalas air susu ibu atau memberi penghargaan terhadap perempuan. Bentuk-bentuk sistem perkawinan adat Manggarai; perkawinan tungku, perkawinan cako, dan perkawinan cangkang. Masyarakat Manggarai perkawinan yang sering dipraktikkan adalah perkawinan cangkang, karena perkawinan ini sesuai dengan ajaran gereja, dan perkawinan yang terjadi di luar suku. Nilai-nilai yang terkandung dalam sistem perkawinan adat Manggarai adalah nilai filosofis, nilai sosial dan nilai ekonomi.

Penelitian lain juga telah dilakukan Diung, Martha, dan Wisudariani dengan judul "Pilihan Bahasa Pada Upacara Perkawinan Adat di Desa Nenu, Kecamatan Cibal, Kabupaten Manggarai”. Hasil penelitian menunjukkan bahwa (1) pilihan bahasa yang digunakan oleh ketua 
adat pada upacara perkawinan adat adalah bahasa Manggarai, (2) dasar pilihan bahasa yang digunakan oleh ketua adat bersifat tradisi atau pemertahanan tradisi dan berkaitan dengan adiluhur bahasa Manggarai, dan (3) pilihan bahasa yang digunakan pada upacara perkawinan adat mengandung makna yang dalam mengenai makna hidup dan kehidupan dalam keluarga. Selain kedua penelitian di atas, penelitian lain juga dilakukan oleh Yohanes Lon dengan judul "Belis dan Hari Perkawinan: Perempuan Dalam Budaya Manggarai, Flores" (2017).

Hasil penelitian menunjukkan bahwa banyak perempuan merasa terbebani oleh belis menjelang dan seputar hari perkawinan, mereka menjadi cemas dan tidak bahagia di hari pernikahan mereka. Mereka ditekan oleh keluarganya sendiri maupun keluarga pria oleh karena masalah belis. Dengan demikian, penelitian ini memperlihatkan kontroversi antara keyakinan adat dan imajinasi sebagian warga mengenai adat belis sebagai bentuk penghargaan terhadap perempuan dengan pengalaman nyata dan kontekstual dari kaum perempuan. Ada jarak antara yang diidealkan dengan kenyataan yang dihadapi. Meskipun demikian, perempuan mempunyai negosiasinya sendiri dalam membuat dirinya bahagia atas relasi dan perkawinannya.

Berdasarkan hasil peneliti terhadap kajian-kajian terdahulu mengenai pernikahan adat Manggarai, kajian-kajian tersebut belum menggali nilai-nilai kearifan lokal yang ada. Padahal kajian mengenai kearifan lokal sangat penting dilakukan untuk mengembalikan dan melestarikan nilai-nilai budaya yang ada. Oleh karena itu, dalam penelitian ini, peneliti berikhtiar mengkaji wujud dan makna kearifan lokal dalam upacara pernikahan adat Manggarai dari perspektif ekolinguistik.

Masalah yang dirumuskan dalam penelitian ini, yaitu (1) bagaimana wujud kearifan lokal dalam upacara pernikahan adat Manggarai ditinjau dari perspektif ekolinguistik? (2) Bagaimana makna kearifan lokal dalam upacara pernikahan adat Manggarai ditinjau dari perspektif ekolinguistik metoaforis? (3) Bagaimana strategi preservasi nilai-nilai kearifan lokal upacara pernikahan adat Manggarai? Berdasarkan masalah yang dirumuskan, tujuan peneltian ini dilakukan, yaitu (1) mendeskripsikan wujud kearifan lokal dalam upacara pernikahan adat Manggarai ditinjau dari perspektif ekolinguistik metaforis. (2) Mendeskripsikan makna kearifan lokal dalam upacara pernikahan adat Manggarai ditinjau dari perspektif ekolinguistik metoaforis. (3) Mendeskripsikan strategi preservasi nilai-nilai kearifan lokal dalam upacara pernikahan adat Manggarai.

Dengan demikian, sangat diharapkan, hasil kajian terhadap wujud dan makna kearifan lokal dalam upacara pernikahan adat Manggarai dapat berkontribusi terhadap perkembangan ilmu bahasa Indonesia. Selain itu, semoga penelitian ini berkontribusi terhadap pelestarian nilainilai budaya yang mulai terkikis akibat perkembangan zaman.

\section{Metode}

Penelitian ini menggunakan pendekatan dan metode kualitatif. Pendekatan kualitatif, yaitu pendekatan ketika mengamati dan menafsirkan realitas dengan tujuan mengembangkan teori yang akan menjelaskan apa yang dialami (Newman\& Ridenour, 1998). Data dikumpulkan dengan metode simak dan metode cakap. Data yang terkumpul diklasifikasikan sesuai dengan kebutuhan pembahasan dan dianalisis menggunakan metode padan. Metode padan merupakan metode analisis bahasa yang alat penentunya di luar, terlepas, dan tidak menjadi bagian dari 
bahasa (langue) yang bersangkutan (Sudaryanto, 2015). Adapun alat penentu yang dimaksudkan dalam penelitian ini ialah 'lingkungan' (dalam arti metaforis) (Nesi, 2018), yaitu lingkup sosial dan budaya masyarakat Manggarai. Analisis data penelitian, peneliti menggunakan metode pada ektralingual, yaitu metode analisis yang digunakan untuk menghubungkan masalah bahasa dengan hal yang ada di luar bahasa (Mahsun, 2012), yakni konteks sosial dan konteks budaya masyarakat Manggarai.

Analisis data ditempuh peneliti berdasarkan prinsip analisis data yang dikemukakan oleh Miles \& Huberman (Nugrahani, 2014), yakni analisis data model interaktif. Analisis data ini memiliki tiga komponen, yaitu (1) reduksi data, (2) sajian data, (3) penarikan kesimpulan/verifikasi. Berdasarkan analisis data model interaktif ini, peneliti menganalisis data sejak pengumpulan data di lapangan dan analisis data dilakukan dalam bentuk siklus. Analisis data dimulai dengan pengumpulan data yang dilakukan secara terus-menerus sehingga peneliti dapat menarik kesimpulan akhir. Apabila simpulan data penelitian yang ditarik masih meragukan, peneliti memulai langkah penelitian dari awal, yaitu memulai kembali pengumpulan data di lapangan, sehingga diperoleh data penelitian baru, sebagai dasar bagi penarikan simpulan dengan lebih mantap.

Ketiga langkah analisis interaktif yang dilakukan peneliti adalah sebagai berikut. (1) Reduksi data, yakni ketika pengumpulan data berlangsung, reduksi data dilakukan dengan membuat catatan ringkas, tentang isi data yang diperoleh dari lapangan. Peneliti melakukan coding, mencari, menentukan batasan penelitian, dan menulis memo. (2) sajian data, yakni peneliti menyajikan data dalam bentuk narasi dan tabel. Pada tahap ini, peneliti mengidentifikasi dan mengklasifikasi data sesuai dengan tujuan penelitian. (3) Penarikan simpulan, yakni peneliti melakukan penafsiran terhadap hasil analisis dan interpretasi data. Penafsiran dilakukan dengan menelusuri kembali semua langkah penelitian, yaitu pemeriksaan data yang terkumpul dan reduksi yang dibuat.

\section{Hasil dan Pembahasan}

Pada bagian ini diuraikan dua hal, yaitu (1) hasil penelitian, (2) pembahasan. Di bagian hasil penelitian disajikan, yakni (1) wujud kearifan lokal dalam upacara adat pernikahan masyarakat Manggarai, (2) makna kearifan lokal dalam upacara adat pernikahan masyarakat Manggarai, dan (3) strategi preservasi kearifan lokal dalam upacara adat pernikahan masyarakat Manggarai. Pada bagian pembahasan disimpulkan kembali mengenai hasil temuan.

Dari hasil penelitian diketahui bahwa (1) pernikahan adat Manggarai terdiri atas beberapa tahap, yaitu pra pernikahan, pernikahan, dan pasca pernikahan. Tahapan tersebut harus dilalui oleh kedua mempelai dengan beragam acara yang dilakukan, seperti tuke mbaru, tukar kila, turuk empo, podo, dan lain-lain. (2) Wujud kearifan lokal upacara adat pernikahan Manggarai ada yang berwujud nyata (tangible) dan berwujud tidak nyata (intangible). Kearifan lokal tangible antara lain, tuak, kala agu raci (sirih dan pinang), paca (belis berupa uang dan hewan), kila (cincin), ruha manuk (telur ayam), manuk lalong bakok (ayam jantan putih). Tuak merupakan minuman beralkohol yang dibuat dari nira aren (kepala, siwalan) yang diragikan (KBBI V) yang digunakan masyarakat Manggarai sebagai media komunikasi adat. Kala agu raci (sirih dan pinang) dipakai oleh orang Manggarai untuk reis (ucapan selamat datang secara 
simbolis). Sirih dan pinang diberikan selama perbincangan adat pernikahan dan disimpan dalam wadah khusus.

Paca (belis) merupakan mahar pernikahan adat Manggarai. Belis biasanya berupa uang dan hewan (kerbau dan kuda). Penetapan belis biasanya berdasarkan kesepakatan antara keluarga wanita dan keluarga pria. Kila (cincin) dikenakan saat upacara paluk kila (tukar cincin). Acara tukar cincin ini dilakukan waktu peminangan awal secara resmi antara laki-laki dan perempuan. Tukar cincin dilakukan apabila peminangan diterima. Ruha manuk atau telur ayam merupakan peranti yang digunakan masyarakat Manggarai dalam upacara gerep ruha (injak telur). Injak telur dilakukan oleh mempelai perempuan saat pertama kali pergi atau masuk ke kampung pria yang telah menjadi suaminya. Telur ayam yang digunakan ialah telur ayam kampung. Kemudian, manuk lalong bakok (ayam jantan putih) adalah hewan kurban sebagai syukuran kehadiran mempelai wanita (istri) dalam keluarga pria.

Sementara itu, kearifan lokal intangible merupakan filosofi masyarakat Manggarai mengenai pernikahan. Pernikahan adat Manggarai mengandung unsur filosofis yang menggambarkan jati diri masyarakat Manggarai. Aspek filosofis mengenai pernikahan adat termanifestasi dalam peribahasa (goet), seperti acer nao wase wunut (kayu tonggak pagar lenjuang tali ijuk enau). Ungkapan ini digunakan oleh juru bicara kedua keluarga setelah terdapat kesepakatan tentang urusan pelaksanaan pernikahan. Ungkapan ini juga digunakan sebagai salah satu ujud doa. Selain itu, terdapat juga ungkapan seperti wa'a wae toe lelo, usang mela toe kira (demi cinta banjir pun tidak dihiraukan, hujan pembawa penyakit pun diacuhkan), bahkan ada ungakapan sotor wae botol agu ata mbeko (meminta bantuan dukun untuk menggaet gadis impian). Kedua ungkapan tersebut menunjukkan bahwa pernikahan atau hidup berkeluarga sangat penting bagi masyarakat Manggarai. Ada goet seperti wua raci tuke, lebo kala tuke (pinang berbuah panjat, sirih bertunas panjat).

Melalui ungkapan ini, orang Manggarai menganggap pernikahan sangat penting demi melanjutkan keturunan. Berdasarkan uraian di atas, disimpulkan bahwa terdapat kearifan lokal dalam upacara adat pernikahan Manggarai. Selain ungkapan di atas, masih banyak lagi ungkapan dalam upacara pernikahan adat Manggarai yang dibahas pada poin makna kearifan lokal. Ungkapan di atas mewakili ungkapan lain untuk membedakan wujud kearifan lokal tangible dan intangible dalam pernikahan adat Manggarai. Pada bagian berikut ini, diuraikan secara berurutan makna dari kearifan lokal yang tangible dan intangible. Terlebih dahulu diuraikan makna dari kearifan lokal yang tangible, kemudian diuraikan kearifan lokal yang intangible.

Pertama, kearifan lokal tangible berupa tuak, kala agu raci (sirih dan pinang), belis (mahar pernikahan berupa uang dan hewan), kila (cincin), ruha manuk (telur ayam), manuk lalong bakok (ayam jantan putih). Tuak, sebagaimana dijelaskan sebelumnya adalah minuman beralkohol yang dibuat dari nila arin yang diragikan (KBBI V) yang digunakan dalam beragam jenis upacara adat Manggarai, bukan hanya dalam pernikahan adat Manggarai. Pada umumnya, tuak digunakan dalam upacara tiba meka (terima tamu), dalam konteks pernikahan tuak digunakan untuk menyambut kedatangan keluarga mempelai laki-laki, yang biasanya disertai ungkapan (goet). Berdasarkan hasil analisis, tuak mengandung makna simbolik, ketulusan. Melalui tuak, orang Manggarai menunjukkan ketulusan menerima seseorang atau kelompok orang yang dianggap sebagai meka (tamu). 
Sirih dan pinang, sebagaimana dijelaskan sebelumnya bahwa sirih dan pinang dipakai oleh orang Manggarai untuk reis (ucapan selamat datang secara simbolis). Sirih dan pinang diberikan selama upacara adat pernikahan dan disimpan dalam wadah khusus. Bagi masyarakat Manggarai, sirih dan pinang bermakna simbolik, yakni persaudaraan. Belis, sebagaimana dijelaskan sebelumnya ialah mahar pernikahan berupa uang dan hewan. Besarnya belis biasanya ditentukan berdasarkan kesepakatan antara keluarga laki-laki dan keluarga perempuan. Belis bukan sekadar kesepakatan, melainkan pengukuhan hubungan suami istri. Berdasarkan hasil analisis, belis mengandung makna simbolik, yaitu ikatan. Filosofi dasarnya adalah pernikahan bukan sesuatu yang bersifat temporal, melainkan berdampak pada suatu hubungan yang berkelanjutan sampai kepada generasi-generasi berikutnya.

Kila (cincin) juga merupakan peranti yang digunakan dalam pernikahan adat Manggarai. Cincin digunakan saat upacara paluk kila (tukar cincin). Acara tukar cincin ini dilakukan waktu peminangan awal secara resmi antara laki-laki dan perempuan yang disaksikan oleh kedua belah pihak. Prosedurnya, tukar cincin dilaksanakan bila peminangan itu diterima. Saat melakukan tukar kila kedua mempelai saling mengungkapkan goet: nana (enu), ho'o kila tanda ngoeng daku ite (nana (sapaan untuk laki-laki); enu (sapaan untuk perempuan), ini cincin tanda bahwa pilihan saya adalah kamu). Dari uraian di atas diketahui bahwa cincin mengandung makna simbolis, yaitu cinta.

Kemudian, ruha manuk atau telur ayam adalah salah satu peranti pernikahan yang digunakan dalam acara puncak pernikahan, yaitu gerep ruha (injak telur). Upacara gerep ruha merupakan upacara di mana mempelai wanita menginjak telur saat pertama kali pergi atau masuk ke kampung mempelai pria. Hal ini berdasarkan adat ritualnya, sebelum masuk ke dalam rumah pengantin pria, pengantin wanita harus menginjak telur ayam di depan pintu rumah pengantin pria. Berdasarkan hasil analisis, diketahui makna simbolik dari telur ayam, yaitu inisiasi, yakni peresmian pengantin wanita dalam tatanan hidup pengantin pria. Selanjutnya, kedatangan pengantin wanita ke keluarga pengantin pria perlu disyukuri agu ca lalong bakok (dengan satu ayam jantan putih). Jadi, setelah acara gerep ruha manuk selesai dan pengantin wanita masuk ke dalam rumah pengantin pria, keluarga laki-laki mengadakan syukuran dengan mengurbankan satu ayam jantan putih, dalam artian keluarga menerima pengantin wanita dengan hati yang bersih (ketulusan). Dengan demikian, ayam jantan putih mengandung makna ketulusan bagi masyarakat Manggarai.

Kedua, kearifan lokal intangible dalam upacara adat pernikahan Manggarai berupa ungkapan-ungkapan (goet) sebagai dasar filosofis masyarakat Manggarai mengenai pernikahan. Ungkapan weda rewa tuke mbaru (injak pintu masuk/bertamu rumah) adalah goet yang digunakan saat pertama kali keluarga laki-laki mendatangi rumah keluarga perempuan dalam rangka melamar. Ungkapan tersebut mengandung makna sopan santun. Selain itu, terdapat ungkapan lain saat prosesi lamaran, yaitu lambu mbaru lejong leso ami, landing le ita kala le pang, rasi peang lawi. Itu manga tuluk kutu batu mbau lami (bertamu ke rumah karena melihat gadis atau perempuan, sehingga mencari tahu dan menemukan tempat tinggalnya). Lambang yang digunakan dalam ungkapan adalah kala agu raci (sirih dan pinang). Masyarakat Manggarai melambangkan seorang gadis seperti sirih dan pinang.

Ungkapan acer nao wase wunut adalah filosofi masyarakat Manggarai mengenai 
pernikahan. Acer noa artinya tonggak pagar dibuat dari pohon lenjuang, sedangkan wase wunut artinya tali pengikat pagar ijuk enau yang telah dipilin. Berdasarkan hasil analisis, ungkapan di atas mengandung makna asosiasi. Makna asosiasi adalah makna yang dimiliki sebuah kata berkenaan dengan adanya hubungan kata itu dengan keadaan di luar bahasa. Lambang yang digunakan adalah (1) acer (kayu tonggak pagar), menurut kebiasaan tonggak pagar menggunakan kayu, (2) nao (pohon lenjuang) salah satu pohon yang dipilih untuk pagar karena stek nao bisa bertunas dan tahan panas, (3) wase wunut (tali ijuk yang telah dipilin) digunakan sebagai pengikat pagar, karena kuat dan tahan lama (tahan lapuk). Ungkapan acer nao wase wunut perumpamaan tentang kehidupan rumah tangga yang terikat dalam persatuan serta bertahan terhadap tantangan dan cobaan.

Ungkapan wa'a wae toe lelo, usang mela toe kira (demi cinta banjir pun tidak dihiraukan, hujan pembawa penyakit pun diacuhkan). Berdasarkan hasil analisis diketahui makna ungkapan tersebut bermakna asosiasi, yakni perjuangan. Dasar pernikahan adat Manggarai adalah cinta laki-laki dan perempuan yang ingin disatukan dalam ikatan bernama keluarga. Ungkapan di atas menggambarkan perjuangan seorang lelaki untuk mendapatkan jantung hatinya. Ungkapan ho'o ca libo, dumpu ca sora mata, titut nggitu deng hitu, o hae gereng sala (hanya ada satu kolam kecil, kudapati satu udang kecil, terimalah dulu, sambil mencari yang lain kemudian). Ungkapan di atas bermakna konotatif. Makna konotatif dapat dilihat dari lambang yang digunakan, yaitu sora mata (udang kecil) dan libo (kolam kecil). Ungkapan tersebut melambangkan kerendahan hati dari pihak keluarga laki-laki yang sadar akan kekurangan bahwa belum bisa melunasi belis. Secara konotatif, melalui ungkapan ini keluarga laki-laki memohon kerendahan hati kepada keluarga perempuan untuk memberi waktu kepada keluarga laki-laki melunasi belis. Hal itu tercermin melalui penggalan titut nggitu deng hitu, o hae gereng sala (terimalah dulu, sambil mencari yang lain kemudian). Dengan demikian, belis merupakan suatu kelanjutan yang menandai hubungan kekerabatan (woe nelu). Dengan kata lain, belis merupakan suatu budaya yang melanggengkan hubungan.

Ungkapan wua raci tuke, lebo kala tuke (pinang berbuah panjat, sirih bertunas panjat). Melalui ungkapan ini, orang Manggarai menganggap pernikahan sangat penting demi melanjutkan keturunan. Lambang yang digunakan adalah kala dan raci (sirih dan pinang). Bagi masyarakat Manggarai, keturuana harus banyak seperti buah pinang dan daun sirih. Ungkapan eme wakak betong asa manga waken nipu tae, eme muntung pu'u gurung-manga wungkutn te ludung (Bambu tua mesti mati, mesti diganti dengan bambu tunas-tunas muda). Ungkapan ini merupakan salah satu dasar filosofis masyarakat Manggarai mengenai pernikahan bahwa tujuan dari pernikahan ialah melanjutkan keturunan. Dengan kata lain, melalui pernikahan, generasigenerasi penerus dilahirkan. Lambang yang digunakan dalam ungkapan di atas ialah betong (bambu), dari lambang tersebut diketahui bahwa ungkapan tersebut bermakna asosiasi. Masyarakat Manggarai mengibaratkan kehidupan manusia seperti bambu, artinya setiap manusia pasti mati. Oleh karena itu, harus ada generasi yang dapat melanjutkan keturunan.

Berangkat dari uraian mengenai wujud dan makna, peneliti telah mengidentifikasi empat strategi preservasi kearifan lokal dalam pernikahan adat Manggarai, yaitu (1) melalui pewarisan alamiah (Nesi, 2018), (2) melalui keluarga, (3) melalui lembaga pendidikan dan (4) pengajaran agama. Menurut penulis, keempat strategi di atas adalah kekuatan agar dapat mewariskan 
kearifan-kearifan lokal kepada generasi penerus. Sebagaimana yang telah diuraikan pada hasil penelitian, peneliti telah mengidentifikasi enam kearifan lokal tangible dan enam kearifan lokal intangible. Secara keseluruhan, data yang diidentifikasi peneliti berjumlah dua belas data. Berdasarkan identifikasi peneliti, kearifan lokal tangible berupa tuak, sirih dan pinang, belis, cincin, telur ayam, dan ayam jantan putih mengandung makna simbolik, seperti ketulusan, ikatan, cinta dan inisiasi.

Makna-makna yang terkandung merupakan dasar filosofis masyarakat Manggarai mengenai pernikahan itu sendiri. Namun dari beberapa peranti yang digunakan di atas, peranti yang menjadi ciri khas pernikahan adat Manggarai adalah belis. Apabila perundingan mengenai belis mencapai kata sepakat, maka tahapan pernikahan yang selanjutnya dapat dilanjutkan. Jeli dan Purawati (2019) mengungkapkan bahwa seorang laki-laki tidak dapat menikahi seorang gadis secara adat apabila belisnya tidak sesuai dengan kesepakatan, karena belis merupakan suatu nilai yang dijunjung tinggi dalam perkawinan adat masyarakat Manggarai, tidak ada perkawinan adat tanpa belis karena di sinilah letak keunikan dan kekhasan perkawinan adat masyarakat Manggarai.

Menurut Verheijen (Boiylon, 2016), belis pada masyarakat Manggarai dikenal dengan sebutan paca yang secara harafiah berarti mas kawin, belis, jujur, pembayaran, membayar. Paca terdiri dari hewan seperti kerbau dan kuda (kaba agu jarang paca) yang biasa disebut pe'ang tana (di luar rumah, karena belis diserahkan di luar rumah) dan uang belis (doi pongo) yang biasa disebut penag tana (di dalam rumah-karena belis diserahkan di dalam rumah (Boylon; Nggoro 2016). Jeli dan Purawati (2019) mengungkapkan bahwa pemberian belis mengandung makna tersendiri, yaitu sebagai ungkapan terima kasih kepada keluarga perempuan karena sudah bersusah payah mengurus, mengasuh, dan membesarkan anaknya dari kecil hingga dewasa bahkan sampai memperoleh pekerjaan layak bagi sang anak. Pendapat lain disampaikan Boylon (2012) bahwa di Manggarai belis mengandung makna dan simbol kegotongroyongan, penghormatan terhadap perempuan dan keluarga, pengikat dua keluarga besar (woé nelu), legitimasi perkawinan, penentuan hak terhadap anak, stabilitas perkawinan, kemahalan dan kompensasi tenaga kerja (Boylon, 2012).

Senada dengan pendapat tersebut Wahyuningsih (2016) menjelaskan bahwa makna belis dalam perkawinan adat adalah sebagai penghargaan tertinggi terhadap perempuan yang akan dinikahi, hubungan timbal balik antara kedua rumpun keluarga, solidaritas secara intern dari kerabat istri ke kerabat suami sebagai wujud dari kekerabatan baru, dan memiliki nilai sosial budaya. Kedua pendapat tersebut, dapat disimpulkan bahwa belis bermakna asosiasi. Makna asosiasi adalah makna yang dimiliki sebuah kata berkenaan dengan adanya hubungan kata itu dengan keadaan di luar bahasa. Makna asosiasi ini sesungguhnya sama dengan lambanglambang yang digunakan oleh suatu masyarakat bahasa untuk menyatakan suatu konsep lain (Leech, 2003; Chaer 2014). Makna asosiasi dari belis adalah ikatan antara dua keluarga besar. Jadi, belis bukan sekadar kesepakatan, melainkan ikatan hubungan persaudaraan antara keluarga besar.

Selain belis sebagai kekhasan pernikahan adat di Manggarai, lima kearifan lokal tangible lainnya, seperti tuak, sirih dan pinang, cincin, telur ayam, dan ayam jantan putih mengandung makna dan nilai yang dijadikan pedoman hidup orang Manggarai. Tuak, selain sebagai saran 
komunikasi, juga digunakan untuk reis meka (penyambutan tamu). Reis menjadi bagian dari konsep komunikasi dalam adat Manggarai (Ndung, 2019). Pada konteks pernikahan, tuak dijadikan sebagai sarana komunikasi antara kedua keluarga dan reis (reis keluarga laki-laki yang datang melamar). Tuak menjadi lambang penyerahan seluruh harapan kepada tamu yang datang untuk bergembira bersama semua warga kampung (Ndiung, 2017). Demikian pula dalam acara pernikahan adat, tuak sebagai lambang penyerahan harapan agar kedua keluarga dapat menyatu sebagai keluarga. Dengan demikian, tuak bermakna asosiasi, yaitu ketulusan hati. Ketulusan hati dalam menerima kehadiran meka (tamu).

Sirih dan pinang, telah dijelaskan pada poin sebelumnya bahwa sirih dan pinang diberikan selama upacara pernikahan adat. Biasanya, yang bertugas memberikan sirih pinang adalah perempuan. Sirih pinang diberikan tanpa pernyataan adat. Masyarakat biasanya menyebutnya pandeng сера. Setelah menyapa tamu, pertama-tama diberikan sirih pinang. Sirih pinang dalam kebudayaan Manggarai dipakai sebagai reis (ucapan selamat datang secara simbolis) (Ndiung, 2017). Jadi, sama halnya dengan tuak, sirih pinang juga sebagai peranti dalam menerima tamu. Sirih dan pinang dicampur dengan kapur sirih yang dalam pemakaiannya tidak segera habis, tetapi tetap disimpan dalam wadah khusus. Kapur sirihlah yang menghasilkan warna dan tahan lama (Ndiung, 2017). Dengan demikian, disimpulkan bahwa sirih pinang bermakna asosiasi, yakni persaudaraan antara keluarga laki-laki dengan keluarga perempuan. Ciri sirih pinang yang berwarna hijau, menghasilkan warna, dan bertahan lama melambangkan persaudaraan yang teduh, berwarna, dan bertahan lama bagi masyarakat Manggarai. Hal yang sama juga dijelaskan Ndiung (2017) bahwa sirih pinang adalah tanda masuk dan mengecap suasana persekutuan.

Konteks pernikahan secara umum, cincin menjadi peranti yang wajib ada. Namun, barangkali setiap daerah memberikan pemaknaan yang berbeda terhadap cincin, dalam budaya Manggarai ketika kedua mempelai saling mengenakan cincin di jari manis, biasanya disertai dengan ungkapan, yaitu momang tu'ung laku ite tedeng wa nai (saya benar-benar mencintai kamu dari hati). Dari uraian tersebut, disimpulkan bahwa cincin simbol cinta kasih dalam kebudayaan Manggarai. Cincin yang berbentuk lingkaran melambangkan hubungan yang tidak pernah putus. Dengan demikian, masyarakat Manggarai mengasosiasikan cincin dengan cinta kasih. Kemudian telur ayam kampung, yaitu peranti yang digunakan dalam ritual gerep ruha manuk (injak telur ayam) (lihat di bahasan sebelumnya). Gerep ruha adalah bagian dari acara podo. Ritual ini dilakukan apabila kedua belah pihak keluraga menyepakati untuk melaksanakan acara podo. Berdasarkan hasil wawancara, ruha (telur) adalah simbol keturunan. Oleh karena itu, ada ungkapan dalam ritual ini, yaitu borek cala bocel ta' $i$ cala wai. Penulis belum menemukan terjemahan secara gamblang dalam bahasa Indonesia mengenai ungkapan tersebut.

Namun, ungkapan tersebut memberi maksud bahwa saat mempelai wanita menginjak telur dan percikan telur mengenai betis dan kaki mempelai perempuan, berarti dalam hidup berkeluarga kedua mempelai akan memperoleh banyak keturunan. Ungkapan tersebut adalah doa agar kedua mempelai memperoleh banyak keturunan seperti percikan telur yang mengenai kaki dan betis mempelai perempuan. Dengan demikian, telur ayam mengandung makna asosiasi, yakni banyak keturunan. Kehadiran mempelai perempuan dalam tatanan hidup mempelai lakilaki perlu disyukuri dengan manuk lalong bakok (ayam jantan putih). Berdasarkan hasil 
wawancara, ayam jantan putih memberi arti bahwa keluarga laki-laki menerima kehadiran mempelai perempuan sepenuh hati. Dengan demikian, masyarakat Manggarai mengasosiasikan ayam jantan putih dengan ketulusan.

Sementara itu, kearifan lokal intangible yang diidentifikasi peneliti berupa ungkapanungkapan (goet) yang dijadikan dasar filosofis masyarakat Manggarai mengenai upacara adat pernikahan, seperti dalam ungkapan Ungkapan acer nao wase wunut perumpamaan tentang kehidupan rumah tangga yang terikat dalam persatuan serta bertahan terhadap tantangan dan cobaan. Berdasarkan analisis peneliti, ungkapan ini mengandung makna asosiatif, karena ada lambang yang digunakan, yaitu acer noa artinya tonggak pagar dibuat dari pohon lenjuang dan wase wunut artinya tali pengikat pagar ijuk enau yang telah dipilin. Ungkapan acer nao wase wunut perumpamaan tentang kehidupan rumah tangga yang terikat dalam persatuan serta bertahan terhadap tantangan dan cobaan (Hemo, 1990).

Ungkapan weda rewa tuke mbaru (injak pintu masuk/bertamu rumah) adalah goet yang digunakan saat pertama kali keluarga laki-laki mendatangi rumah keluarga perempuan dalam rangka melamar. Ungkapan tersebut menggambarkan tata cara melamar seorang gadis. Ibarat bertamu, seseorang harus mengetuk pintu atau memberi salam kepada tuan rumah terlebih dahulu. Ungkapan ini memberi pesan bahwa seorang pria harus melamar seorang gadis secara resmi baru dinikahi secara adat atau agama, tanpa ada hubungan gelap. Berdasarkan hasil wawancara, ungkapan tersebut mengandung makna asosiatif, yakni sopan santun. Selain itu, terdapat ungkapan lain saat prosesi lamaran, yaitu lambu mbaru lejong leso ami, landing le ita kala le pa'ang, rasi peang lawi. Itu manga tuluk kutu batu mbau lami (bertamu ke rumah karena melihat gadis atau perempuan, sehingga mencari tahu dan menemukan tempat tinggalnya). Lambang yang digunakan dalam ungkapan adalah kala agu raci (sirih dan pinang).

Masyarakat Manggarai melambangkan seorang gadis seperti sirih dan pinang. Hal senada juga disampaikan Diung, Martha, \& Wisudariani (2017) bahwa arti harafiah dari kata 'kala le pa'ang, raci peaang lawir' adalah sirih di luar pinang di dalam. Namun dalam konteks ini, ungkapan kala le pa'ang, raci peaang lawir' diartikan sebagai gadis yang selama ini dicari yang ingin diminang oleh mempelai laki-laki. Dengan demikian, kala agu raci mangandung makna asosiasi, yaitu gadis.

Ungkapan wa'a wae toe lelo, usang mela toe kira (demi cinta banjir tidak dihiraukan, hujan pembawa penyakit diacuhkan). Dasar pernikahan adat Manggarai adalah cinta laki-laki dan perempuan yang disatukan dalam ikatan bernama keluarga. Ungkapan di atas mengambarkan perjuangan seorang lelaki untuk mendapatkan jantung hatinya. Berdasarkan hasil wawancara dan analisis, ungkapan tersebut bermakna asosiasi, yakni perjuangan. Ungkapan ho'o ca libo, dumpu ca sora mata, titut nggitu deng hitu, o hae gereng sala (hanya ada satu kolam kecil, kudapati satu udang kecil, terimalah dulu, sambil mencari yang lain kemudian). Lambang yang digunakan dalam ungkapan tersebut adalah libo (kolam kecil) dan sora mata (udang kecil). Ho'o cal libo dan ca sora mata berarti ini satu kolam kecil dan satu udang kecil. Ungkapan ini digunakan saat perundingan belis antara kedua bela pihak. Berdasarkan wawancara, ungkapan tersebut bermakna asosiatif, yaitu kerendahan hati. Ungkapan tersebut disampaikan pihak keluarga laki-laki kepada pihak keluarga perempuan untuk meminta kebijakan mengenai permintaan belis. Ibarat sebuah kolam kecil yang hanya 
hidup satu udang kecil, keluarga laki-laki menggambarkan keadaannya yang belum bisa membayar belis dengan lunas.

Ungkapan wua raci tuke, lebo kala tuke (pinang berbuah panjat, sirih bertunas panjat). Melalui ungkapan ini, orang Manggarai menganggap pernikahan sangat penting demi melanjutkan keturunan. Ungkapan ini sebagai doa agar kedua mempelai yang menikah mendapat banyak keturunan seperti banyaknya buah pinang dan tunas sirih yang selalu tumbuh. Jadi, sirih dan pinang diasosiasikan dengan keturunan. Ungkapan eme wakak betong asa manga waken nipu tae, eme muntung pu'u gurung-manga wungkutn te ludung (Bambu tua mesti mati, mesti diganti dengan bambu tunas-tunas muda). Lambang yang digunakan dalam ungkapan tersebut adalah betong (bambu). Dalam kebudayaan Manggarai, manusia hidup ibarat bambu, yang pasti akan tua dan mati. Dengan demikian, harus ada keturunan sebagai generasi penerus. Demikian halnya dengan pernikahan, pernikahan dilakukan dengan tujuan melanjutkan keturunan.

Apabila kita mencermati peranti dan ungkapan yang digunakan masyarakat Manggarai dalam upacara adat pernikahan, semua makna yang terkandung di dalamnya memiliki nilai-nilai yang berguna bagi kehidupan masyarakat Manggarai. Selain itu, pilihan bahasa perkawinan adat adalah saluran utama dalam berkomunikasi (Diung, Martha, \& Wisudariani, 2017). Bahkan, pilihan bahasa membentuk keharmonisan dalam berkomunikasi. Selain itu, kearifan lokal, baik tangible maupun intangible mengandung unsur alam. Hal itu terbukti melalui peranti seperti tuak, hewan, telur ayam, dan ayam jantan putih. Selain itu, dapat kita cermati melalui ungkapan yang menggunakan lambang bambu, enau, sirih dan pinang. Hal tersebut menunjukkan identitas diri masyarakat Manggarai. Ndia (2012) mengatakan makna bahasa tidak bisa berdiri sendiri tanpa dikorelasikan dengan konteks budaya. Inilah yang disebut hubungan dialektikal, bahwa bahasa dan lingkungan saling mempengaruhi.

Hal ini sesuai dengan pandangan Haugen, pencetus ekolinguistik metaforis. Haugen menggunakan konsep lingkungan bahasa secara metaforis, yakni dipahami sebagai masyarakat pengguna bahasa, sebagai salah satu kode bahasa, bahasa berada hanya dalam pikiran penuturnya, dan oleh karenanya bahasa berfungsi hanya apabila digunakan untuk menghubungkan antar penutur, dan menghubungkan penutur dengan lingkungannya, baik lingkungan sosial atau lingkungan alam (Subiyanto, 2013).

Ungkapan bahasa Manggarai menggunakan unsur alam juga disampaikan (Diung, Martha, \& Wisudariani, 2017) bahwa pilihan bahasa yang digunakan dalam upacara adat pernikahan Manggarai berkaitan dengan lambang-lambang alam dengan perumpamaan. Masyarakat Manggarai selalu memandang bahwa alam menjadi contoh harmonisasi kehidupan bagi masyarakat. Jadi, ungkapan-ungkapan bernuansa alam tersebut sarat makna dan mengandung pesan yang ingin disampaikan kepada mitra tutur.

Akhirnya, kearifan lokal, baik tangible maupun intangible tentunya mengandung nilainilai yang dapat dijadikan pedoman hidup bagi masyarakat Manggarai. Oleh karena itu perlu adanya upaya preservasi. Adapun strategi preservasi yang diidentifikasi peneliti, yaitu (1) pewarisan alamiah, (2) melalui keluarga, (3) melalui lembaga pendidikan, (4) melalui lembaga agama. Peran keluarga sangat penting dalam melestarikan kearifan lokal kepada anak. Orang tua dapat mewariskan kearifan-kearifan lokal dalam upacara pernikahan adat dengan (1) pengajaran, yakni mengajar kearifan-kearifan lokal dalam pernikahan adat kepada anak; (2) orang tua dapat 
memotivasi anak untuk selalu terlibat dalam upacara-upacara adat daerah, seperti pernikahan.

Sementara itu, strategi preservasi melalui lembaga pendidikan dapat dilakukan dengan (1) mengembangkan kurikulum pembelajaran bahasa yang bermuatan kearifan lokal dalam upacara adat pernikahan Manggarai, (2) mengembangkan buku ajar yang bermuatan kearifan lokal dalam upacara adat pernikahan Manggarai. Pada bagian pengajaran agama, peran gereja sangat penting. Gereja dapat mewariskannya melalui katekese atau khotbah yang bermuatan kearifan lokal dalam upacara adat pernikahan Manggarai. 


\section{Simpulan}

Berdasarkan uraian pada hasil dan pembahasan, beberapa hal disimpulkan (1) wujud kearifan lokal dalam upacara pernikahan adat Manggarai berwujud nyata (tangible) dan berwujud tidak nyata (intangible). Kearifan lokal tangible adalah kearifan berupa benda atau fisik, seperti kila (cincin), ruha manuk (telur ayam), tuak, manuk lalong bakok (ayam jantan putih), dan paca (belis). Sementara itu, kearifan lokal intangible barupa ungkapan-ungkapan (goet) sebagai dasar filosofi masyarakat Manggarai mengenai pernikahan. Kearifan lokal tangible dalam upacara pernikahan adat Manggarai mengandung makna asosiatif, yaitu, persaudaraan, ketulusan hati, persaudaraan, cinta kasih dan keturunan. Sementara itu, Kearifan lokal intangible berupa ungkapan-ungkapan (goet) dalam pernikahan adat Manggarai mengandung makna asosiatif, yaitu sopan santun, gadis, perjuangan, kerendahan hati, keturunan. Akhirnya, sebagai upaya pelestarian kearifan lokal dalam upacara adat pernikahan Manggarai, ada empat strategi yang dilakukan, yaitu (1) pewarisan alamiah, (2) pewarisan melalui keluarga, (3) pewarisan melalui lembaga pendidikan, (4) dan pewarisan melalui lembaga agama.

Kajian mengenai wujud dan makna kearifan lokal dalam upacara pernikahan adat Manggarai ini tidak luput dari kekurangan atau kelemahan. Oleh karena itu, ada beberapa keterbatasan dalam penelitian ini, yaitu (1) akibat keterbatasan waktu penelitian, masih banyak kearifan-kearifan lokal dalam pernikahan adat Manggarai yang tidak tercatat dalam penelitian ini; (2) sebagian data dalam penelitian ini diperoleh melalui wawancara via telepon, sehingga tidak mendapat gambaran data yang mendalam; (3) sebagian data belum dianalisis secara mendalam akibat keterbatasan sumber; dan (4) sebagian data belum diterjemah secara gambling ke dalam bahasa Indonesia, sehingga analisis tidak mendalam. Berangkat dari keterbatasan yang ada, peneliti berjanji untuk menutup kelemahan pada penelitian yang lain. Selain itu, peneliti menyarankan kepada peneliti lain agar melakukan penelitian serupa dengan fokus yang serupa guna mendapat gambaran yang spesifik dan signifikan mengenai kearifan-kearifan lokal yang terdapat dalam upacara pernikahan adat Manggarai, serta demi menggali nilai-nilai kebudayaan dan melestarikan kearifan lokal yang terancam punah.

\section{Daftar Pustaka}

Boy Lon, Yohanes Servatius. 2012. "Perkawinan menurut Adat Manggarai: Dalam Perspektif Hukum Gereja Katolik”. Dalam Chen Martin dan Suwendi Charles. Iman, Budaya \& Pergumulan Sosial. Jakarta: Penerbit Obor.

Boylon, S.Y \& Fransiska Widyawati. (2016). Belis dan Hari Perkawinan: Perempuan dalam

Budaya Manggarai, Flores. International Conference on Social Sciences and Humanities (ICSSH), LIPI, 2016.

Chaer, A., \& Liliana Muliastuti. (2014). Makna dan Semantik. 1-39. http://repository.ut.ac.id/4770/1/PBIN4215-M1.pdf

Cresswel, J. W. (2010). Research Design: Pendekatan Kualitatif, Kuantitatif, dan mixed. Yogyakarta: Pustaka Belajar.

Departemen Pendidikan dan Kebudayaan Pusat Penelitian Sejarah dan Budaya (Proyek 
Penelitian dan Pencatatan Kebudayaan Daerah). (1977/1978). Adat Istiadat Daerah Nusa Tenggara Timur.

Diung, Martha, \& Wisudariani. (2017). Pilihan bahasa pada upacara perkawinan adat di desa nenu, kecamatan cibal, kabupaten manggarai. 1.

Elliason, Stig. 2015. The birth of language ecology: interdisciplinary influencesin Einar

Haugen's "The ecology of language”. Jurnal Language Sciences.

Fajarini, Ulfah. (2014). Peranan Kearifan Lokal dalam Pendidikan Karakter. Universitas Islam Negeri (UIN) Syarif Hidayatullah Jakarta: Sosio Didaktika, Volume 1, No 2 Desember 2014.

Francke, N., Verlag, A., \& Co, G. (2020). Narr Francke Attempto Verlag GmbH Co . KG Ecolinguistics - State of the Art 1998 Author (s): Alwin Fill Source: AAA : Arbeiten aus Anglistik und Amerikanistik, Vol . 23, No . 1 (1998), pp . 3-16 Published by: Narr Francke Attempto Verlag GmbH Co. KG Stable URL: https://www.jstor.org/stable/43025552 Ecolinguistics - State of the Art 1998. 23(1), 316.

Haugen, Einar. (1972). The Ecology of Language. Stanford, California: Standford University Press.

Hemo, Doroteus. (1990). Ungkapan Bahasa Daerah Manggarai NTT.

Ihromi. 2017. Pokok-pokok Antropologi Budaya. Jakarta: Yayasan Pustaka Obor Indonesia.

Jeli, O. S., \& Purawati, N. K. (2019). Sistem Perkawinan Adat Manggarai Dalam Perspektif Gender, Desa Nggalak Kecamatan Reok Barat Kabupaten Manggarai Tengah. 07(1).

Leech, Geoffrey. (2003). Semantik. Pustaka Pelajar: Yogyakarta.

Lier, Van Leo. (2004). The Ecology and Semiotics of Languade Learning A Sociocultural Perspective. Boston: Kluwer Academic.

Lon, Yohanes (2017) Belis dan Hari Perkawinan: Perempuan Dalam Budaya Manggarai, Flores. In: "Strengthening the Role of Social Sciences and Humanities in the Global Era. IPSK LIPI, Jakarta, Indonesia, pp. 1055-1070. ISBN 978-602-608446-0-6

Mahsun. (2012). Metode Penelitian Bahasa. Jakarta: Rajawali Pers.

Muhlhausler, Peter. (1990). Linguistic Ecology. London: Routledge.

Ndia, Y. M. (2012). Kajian Semiotik Bahasa Pernikahan Adat Budaya Flores Kabupaten Manggarai Barat Nusa Tenggara Timur. Yogyakarta, U. N., Sastra, S.,

Ndiung, S. (2017). Ritus Tiba Meka Orang Manggarai Dalam Kajian Etnopedagogi. The Ist International Conference On Language, Literature and Teaching, 827.

Ndung, Yustina. (2019). Etos Kerja dan Spirit Hidup Orang Manggarai. Malang: Universitas Negeri Malang.

Nesi, Antonius. (2018). Tradisi Lisan Takanab Sebagai Wujud Identitas Masyarakat Dawan:

Kajian Ekolinguistik Metaforis. Tesis. Yogyakarta: Fakultas Keguruan dan Ilmu Pendidikan Universitas Sanata Dharma.

Newman, I., \& Ridenour, C. (1998). Qualitative-Quantitative Research Methodology: Exploring the Interactive Continuum Qualitative-Quantitative Research: A False Dichotomy. Educational Leadership Faculty Publications, 122.

Nugrahani, F. (2014). Metode Penelitian Kualitatif dalam Penelitian Pendidikan Bahasa. 305. 
Diunduh pada http://digilibfkip.univetbantara.ac.id/materi/Buku.pdf tanggal 29 Februari.

Nuzwaty. (2019). Pengenalan Awal Ekolinguistik. Medan: Sastra Uisu Press.

PDSPK. (2016). Analisis Kearifan Lokal Ditinjau Dari Keragaman Budaya. Jakarta: PDSPK Kemdikbud RI.

Rahardi, R., \& Setyaningsih, Y. (2019). Local wisdom values of Javanese children's traditional games: a methaphorical ecolinguistic view. Linguistik Indonesia (Terakreditasi DIKTI; Sinta 2), 37(2), 101-117.

Sofroniou, A. Sofronis. (1989). Structural Semantic of Byzantine Greek. Nicosia: Kykkos Recearch Centre.

Subiyanto, Agus. (2013). Ekolinguistik: Model Analisis dan Penerapannya. Humanika, vol. 18, no. 2, Jul. 2013. https://doi.org/10.14710/humanika.18.2.

Sudaryanto. 2015. Metode dan Teknik Analisis Bahasa: Pengantar Penelitian Wahana Kebudayaan Secara Linguistis. Yogyakarta: Sanata Dharma University Press.

Tarigan, Bahagia. 2016. Kebertahanan dan Kebergseran Leksikon Flora Bahasa Karo: Kajian Ekolinguistik. Disertasi. Medan: Universitas Sumatra Utara.

Troike, Savilee Muriel. (2003). The Etnography Communication. Oxford: Blackwell Publishing. Vitasurya, V. R. (2016). Local Wisdom for Sustainable Development of Rural Tourism, Case on Kalibiru and Lopati Village, Province of Daerah Istimewa Yogyakarta. Procedia - Social and Behavioral Sciences, 216 (October 2015), 97-108. https://doi.org/10.1016/j.sbspro.2015.12.014

Wahyuningsih, Sri (2016) Makna Budaya Belis Dalam Perkawinan Adat Bagi Masyarakat (Studi Di Kecamatan Witihama Kabupaten Flores Timur). Other thesis, University of Muhammadiyah Malang. 